\title{
산소유리기와 폐질환
}

중앙대학교 의과대학 내과학교실

서 승 천 허 성 호

\section{The Role of Oxygen Radical in Pulmonary Diseases}

Seung Cheon Seo, M.D. and Sung Ho Hue, M.D.

Department of Internal Medicine, College of Medicine, Jung Ang University, Seoul, Korea

서 론

1954년 Gerschman과 Gilbert는 흡입하는 산소농도 를 증가시킬때 생체내에서 산소유리기 (oxygen free radical) 생성이 증가되며, 이러한 현상이 세포나 조직의 손상과 밀접한 관계가 있음을 발표하였다 ${ }^{11}$.

그러나 이 학설은 1969년 Mccord와 Fridovich가2) 산소유리기를 특이적으로 제거해주는 호소, 즉 Superoxide dismutase (SOD)를 발견하기 전 까지만해도 대 부분의 생물학자나 임상가들의 관심을 끌지 못하였다. 그후 최근 10 여년동안 산소유리기와 관련된 많은 연구결 과가 보고되면서, 현재 이들에 대한 연구는 의생물학 및 분자생물학 중에서 가장 활발히 진행되고 있는 분야중의 하나라고 할 수 있겠다.

생체세포는 여러가지 원인에 의해 과다한 산소유리기 와 접할 수 있다. 흡입하는 산소농도를 증가시키거나 대 기중의 수많은 미립자와 독성물질에 노출되므로서, 또 는 허혈성 장애후 조직의 재관류시에 이러한 현상을 볼 수 있다. 그 외에도 활성화된 식세포는 반응성 산소대사 물을 유리시켜 염증성, 섬유화폐병변 유발에 직접, 간접 으로 관여하고 있다.

산소유리기가 일차적으로 폐손상에 관여하는지는 아 직까지 확실히 밝혀져 있지 않으며, 중요한 것은 조직내 에서 산소유리기가 증가할때 주위세포의 기능장애나 세 포파괴가 있기전에 신속하게 제거된다는 것이다.
정상적으로 폐는 산소가 풍부한 장기이다. 아울러 세 포의 대사과정중에 생기는 반응성 산소대사물과 이를 제 거하기 위한 세포내외의 antioxidant효소가 서로 균형 을 유지하고 있으며, 세포는 항상 산소유리기 형성을 제 한하고, 다양한 antioxidant효소계에 의해 세포내외의 산소유리기 층가에 대처하게 된다. 따라서 유리기가 증 가되거나 antioxidant체계의 작용이 위축될 때 폐세포 의 손상과 파괴가 일어나며 폐질환을 유발시킨다.

본 논문에서는 지금까지 밝혀진 내용을 토대로 산소유 리기의 특성 및 생성과정과 이들에 대한 세포의 방어기 전, 유리기와 관련된 폐질환들에 대하여 살펴보고자 한 다.

\section{산소의 화학적 특성과 산소유리기의 생성}

폐에서 생성되는 산소유리기의 작용기전을 이해하기 위해 먼저 산소의 화학적 성질을 설명하기로 한다.

기저상태의 산소분자 $\left(\mathrm{O}_{2}\right)$ 는 쌍을 이루고 있지않은 두 개의 전자가 서로 다른 최외각 전자케도에 같은 방향의 spin을 갖고 있다 (Fig. 1).

따라서 생체내에서 결합에 참여하지 않는 전자쌍을 갖 고있는 분자들과 쉽게 반응을 할 수가 없다(Fig. 2). 이 러한 현상은 Fig. 2에서 보는바와 같이 쌍을 이룬 전자 두개가 동시에 산소분자에 들어갈때 한 전자게도에는 같 은 방향의 spin을 갓는 전자쌍이 형성되어 "Paulis exclusion원칙"에 어긋나 ${ }^{4)}$ 물리적으로 일어날 수가 없 


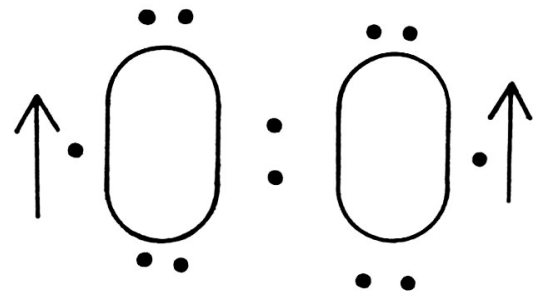

Fig. 1. Electronic configuration of $\mathrm{O}_{2}$.
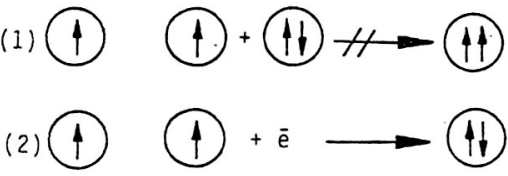

(41)
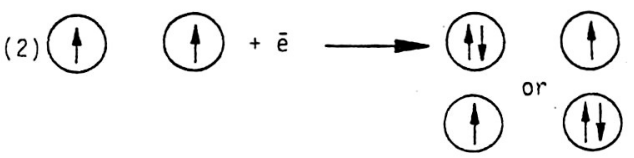

Fig. 2. Dioxygen reduction products. (1) Dioxygen cannot undergo divalent reduction. (2) Dioxygen can be reduced through a series of single electron transfers producing intermediates referred to as "free radicals".

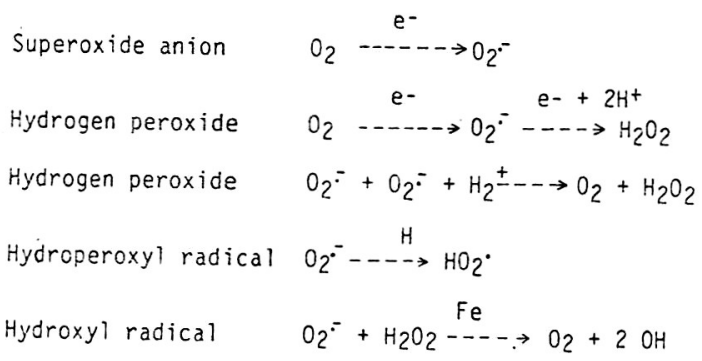

Fig. 3. Intermediate products of the reduction of molecular oxygen.

기 때문이다. 이와같이 산소의 전자배열 특성상 전자두 개를 동시에 받아 들일 수 없는 성질을 "spin restriction"이라 한다"). 따라서 산소분자가 대사되어 최종 산물인 물 $\left(\mathrm{H}_{2} \mathrm{O}\right)$ 로 환원되기 위해서는 정상적으로 호흡 하는 세포는 spin restriction현상을 피하면서 전자가 한 번에 하나씩 들어가는 소위 "univalent reduction 반 응"을 따르거나, 효소작용을 통해 가능하다.

Univalent reduction반응에 따라 산소가 완전히 대사 되어 $\mathrm{H}_{2} \mathrm{O}$ 로 되기전에, 전자를 받아 환원될 때마다 중간 대사물이 생성되는데 이를 산소유리기 (oxygen free radical) 또는 반응성 산소대사물(reactive oxygen
Table 1. Reactive Oxygen Metabolites That have been Implicated in Cellular Processes

\begin{tabular}{ll}
\hline \hline Name & Symbol \\
\hline $\begin{array}{l}\text { Superoxide radical } \\
\text { (Superoxide anion) }\end{array}$ & $\mathrm{O}_{2} \cdot-$ \\
Hydrogen peroxide & $\mathrm{H}_{2} \mathrm{O}_{2}$ \\
Hydroperoxyl radical & $\mathrm{HOO} \cdot$ \\
Hydroxyl radical & $\mathrm{HO} \cdot$ \\
Singlet oxygen & $1 \mathrm{O}_{2}$ \\
Ozone & $\mathrm{O}_{3}$ \\
\hline
\end{tabular}

metabolites)이라한다(Table 1).

전술한바와 같이 산소분자가 전자 4 개를 받아 완전히 환원되면 두 분자의 $\mathrm{H}_{2} \mathrm{O}$ 가 형성된다. 그러나 환원과정 에서 전자를 하나씩 받을때마다 산소의 부분적 환원이 일어나며 이때 반응성이 매우 강한 중간산물이 생기게 된다. 만일 산소분자가 전자 한개를 받아 환원되면 superoxide radical (또는 superoxide anion; $\mathrm{O}_{2}{ }^{-} \cdot$ )이 나 여기에 수소이온이 결합된 hydroperoxyl radical $\left(\mathrm{HO}_{2} \cdot\right)$ 로 된다 ${ }^{6,7}$ (Fig. 3).

Superoxide radical은 반응물질에 따라 산화제나 환 원제로 작용하는데 산화제로 작용할때는 전자 하나를 얻 어 과산화수소 $\left(\mathrm{H}_{2} \mathrm{O}_{2}\right)$ 로 되고, 환원제로 작용시는 전자 하나를 잃고 다시 산소분자로 산화된다. 만일 두분자의 superoxide radical이 동시에 서로 반응할 경우 하나는 산화되고 다른하나는 환원되는데 이를 "dismutation 반 응”이라하며 산소와 과산화수소가 대사산물로 남게된 다. 이 반응을 촉매하는 효소는 superoxide dismutase 이며 생체내의 $\mathrm{pH}$ 에 관계없이 dismutation반응을 촉매 한다. 물론 이 반응은 자발적으로도 일어나나 $\mathrm{O}_{2}{ }^{-}$- 이 많은 상태의 높은 $\mathrm{pH}$ 에서는 자발적 dismutation은 거 의 일어나지 않는다.

$\mathrm{H}_{2} \mathrm{O}_{2}$ 가 전자하나를 더 수용하여 다시 환원되면 hydroxyl radical $(\mathrm{OH} \cdot)$ 이 생성되는데 ${ }^{8)}$ 유리기 중에서 가장 반응성이 강하며 살아있는 세포의 거의 모든 구조 물들에 손상을 준다. $\mathrm{OH} \cdot$ 은 처음의 두 중간산물 즉, $\mathrm{O}_{2}^{-} \cdot$ 과 $\mathrm{H}_{2} \mathrm{O}_{2}$ 를 효과적으로 차단하므로서 생성을 억제 시킬 수 있다. 그러나 생체내에서 $\mathrm{OH}$ - 이 생성되는 중 요한 기전은 "Haber-Weiss 반응"으로 $\mathrm{O}_{2}{ }^{-} \cdot$ 에 의해 $\mathrm{H}_{2} \mathrm{O}_{2}$ 가 환원되면서 $\mathrm{OH}$ - 이 생기게 된다.

$$
\mathrm{H}_{2} \mathrm{O}_{2}+\mathrm{O}_{2}^{-} \cdot \rightarrow \mathrm{O}_{2}+\mathrm{OH}^{-}+\mathrm{OH} \cdot
$$


그러나 실제로 위와같은 반응은 매우 느리게 진행되는 데 그 이유는 $\mathrm{O}_{2}^{-}$-이 $\mathrm{H}_{2} \mathrm{O}_{2}$ 와 반응하기 보다는 dismutation되는 것이 훨씬 빠르기 때문이다. 따라서 생체내에서는 iron $(\mathrm{Fe})$ 이나 copper $(\mathrm{Cu})$ 같은 금속이온 의 촉매작용에 의해 아래와 같은 두 반응이 일어나며, 이 반응은 결국 Haber-Weiss반응과 같게된다.

$$
\begin{aligned}
& \mathrm{O}_{2}^{-} \cdot+\mathrm{Fe}^{3+} \rightarrow \mathrm{O}_{2}+\mathrm{Fe}^{2+} \\
& \mathrm{Fe}^{2+}+\mathrm{H}_{2} \mathrm{O}_{2} \rightarrow \mathrm{Fe}^{3+}+\mathrm{OH}^{-}+\mathrm{OH} \cdot(2)
\end{aligned}
$$

위 반응중 특히 반응 (2)를 "Fenton 반응"이라 한 다 ${ }^{1,4)}$

반응성 산소대사물은 지금까지 살펴본 바와 같이 전자 를 하나씩 수용하는 반응외에도, 총 전자수에는 변화없 이 산소분자가 에너지를 흡수하여 높은 에너지상태로 변 하면서 생길 수도 있다. 예를들면 산소분자는 기저상태 에서 쌍을 이루고 있지 않은 두개의 전자가 서로 같은 방 향의 spin을 가지면서 다른 궤도내에 있는데, 어떤 원인 에 의해 산소분자가 에너지를 흡수하면 excited state가 되어 두개의 전자중 어느 하나는 spin의 방향이 바뀌면 서 보다높은 에너지상태의 게도로 이동된다. 이러한 상 태를 singlet oxygen $\left({ }^{1} \mathrm{O}_{2}\right)$ 이라 하며 새로 형성된 전자 쌍이 같은 케도에 있을때를 $\triangle^{1} \mathrm{O}_{2}$, 각 전자가 서로다른 방향의 spin을 갖으면서 다른 궤도에 위치할때 $\Sigma^{1} \mathrm{O}_{2}$ 이 라 하는데 $\mathrm{OH} \cdot$ 과 더불어 세포손상의 가장 큰 원인이 라 할 수 있다9).

다음은 생체내에서 유리기를 생성할 수 있는 물질이나 기관에 대해 살펴보기로 한다.

폐세포의 cytosol에는 superoxide radical을 생성할 수 있는 많은 저분자 물질들이 있는데 이러한 물질로는 thiols, hydroquinones, catecholamines, flavins 등을 들 수 있다 ${ }^{10)}$. 이 외에도 xanthine oxidase와 같은 많 은 세포질내 효소들도 superoxide radical을 만들어 낼 수 있다. Xanthine oxidase는 xanthine이나 hypoxanthine의 존재하에 산소분자의 환원에 의해 superoxide radical을 생성하는데, 최근에 허혈성질환에서 조직 의 재관류시 나타나는 손상과 관련이 깊을 것으로 보여 이에대한 많은 연구가 진행중이다 ${ }^{111}$.

폐의 mitochondria에서도 유리기가 생성된다. 정상 적으로 cytochrome oxidase의 존재하에 mitochondria에서는 전체 산소의 $95 \%$ 이상이 electron transport chain을 거치면서 환원되어 $\mathrm{H}_{2} \mathrm{O}$ 로 되는데, 이중 약 $1 \sim 2 \%$ 의 electron flow가 $\mathrm{O}_{2}$ 로 빠져나와 $\mathrm{O}_{2}{ }^{-}$. 을
형성한다 ${ }^{122}$.

그러나 일반적으로 mitochondria에서는 $\mathrm{H}_{2} \mathrm{O}_{2}$ 만 배 출되는 것으로 알고 있는데, 이는 $\mathrm{O}_{2}{ }^{-}$- 이 효소에 의해 또는 비효소적으로 dismutate되어 $\mathrm{H}_{2} \mathrm{O}_{2}$ 와 $\mathrm{O}_{2}$ 을 형성 하기 때문일 것이다. Electron transport chain으로부 터 생기는 $\mathrm{O}_{2}{ }^{-} \cdot$ 은 주로 ubiquinone이 부분적으로 환원 되거나 flavoprotein, NADH dehydrogenase에 의한 것으로 보인다. electron transport동안 ubiquinone의 환원에 의해 ubisemiquinone 유리기가 생겨 이 물질이 $\mathrm{O}_{2}$ 과 반응하여 $\mathrm{O}_{2}{ }^{-} \cdot$ 을 만든다.

핵막이나 plasma membrane같은 폐세포의 막 성분 도 유리기를 만들어 낼 수 있으며, 이 또한 매우 중요한 의미를 갖는데 ${ }^{13)}$ 그 이유는 막이 cytosol이나 organelle 의 표면, 세포부위에 가깝게 있기 때문이다.

이들로부터 나온 유리기는 주위의 cytosol이나 세포 외로 확산되어 유리기를 생성해낸 세포뿐 아니라 주변세 포들까지 손상을 입히게 된다. 폐세포에서 plasma membrane이 파괴되면 결국 정상적인 세포기능의 통합 이 어렵게 되어 세포는 죽게된다.

자극을 받은 alveolar macrophage도 많은 chemotaxin을 분비한다. 이에따라 순환하는 백혈구가 혈 관내피세포 표면으로 이동한 후 혈관밖으로 나와 침범된 장기의 간질로 모여 산소대사물을 유리한다. 그 외에도 hyperoxia에 의해 자극을 받은 alveolar macrophage 는 중성구의 결집능력이나 superoxide radical생성을 자극하는 많은 humoral factor를 분비한다.

중성구가 폐조직에 나타나게 되면 활성화되어 식작용 을 하는데 이때 많은 유리기가 분비되며 이들 산소대사 물이 식작용된 세균에 대해 살균효과를 나타낸다. 유리 기의 분비는 주로 plasma membrane이 자극을 받아 일 어나며 이러한 현상을 "respiratory burst"라 하는데" 이때 특징적으로 산소소비와 hexose monophosphate shunt의 활성도가 증가하며 유리기 생성이 증가된다.

조직이 산소대사물에 의해 공격을 받을때 식세포는 손 상받은 상피세포를 포함하여 많은 물질들을 식작용한 다 ${ }^{14)}$. 중성구의 이러한 능력이 한계에 달할때 세포밖으 로 반응성 산소유리기의 배출이 증가될 것이고 궁극적으 로는 오히려 세포손상을 촉진하는 방향으로 작용하게 된 다.

이들 세포는 단백분해물질이나 arachidon산 대사물 을 유리시켜 조직손상에 관여하기도 한다. 
결국 자극을 받아 활성화된 과립세포는 실제로, 유리 기에 의한 폐손상동안 조직 또는 세포손상을 가중시키는 역할을 하는 것이다.

\section{산소유리기에 대한 방어기전}

현재까지 알려진 바에 의하면 패세포는 산소유리기에 의한 손상을 막기위해 다음과 같은 세가지 방어기전을 갖고 있다.

첫째는 지나친 유리기 생성을 방지하도록 세포가 작용 하는 것으로, 산소대사과정중 univalent reduction을 피하는 것이다. 즉, 한 단계로 산소분자가 tetravalent reduction (전자 4개를 수용) 하여 산소의 중간대사물이 형성되지 않고 $\mathrm{H}_{2} \mathrm{O}$ 로 환원되도록 하는 것이다.

둘째는 여러가지 효소나 물질들에 의해 이미 생성된 유리기를 반응성이 약한 물질로 변화시키거나 제거시키 는 것이며 세번째 방어기전은 손상받은 세포부위를 신속 하게 복구하는 것이다.

\section{1. 유리기 생성의 방지}

세포가 유리기 생성을 방지하는 것은 세포의 생존을 위한 가장 기본적인 반응이라 할 수 있다. 그 이유는 세 포의 정상적인 호흡과정중 산소를 이용하면서 산소분자 의 "spin restriction" 성 질에 의해 항상 반응성 산소유리 기가 만들어 지기 때문이다.

Mitochondria에서는 대부분의 산소가 대사되는데, 이때 respiratory chain을 통해 산소의 중간대사물이 많 이 생기지 않으면서 $\mathrm{H}_{2} \mathrm{O}$ 로 환원 시킨다 ${ }^{15.16)}$. 이러한 반 응은 cytochrome oxidase에 의해 산소분자가 divalent 또는 tetravalent reduction하므로서 가능하다. 물론 mitochondria의 electron transport chain으로 부터도 소량의 유리기가 배출되나 대부분이 antioxidant효소에 의해 처리되어 다른 세포성분들과 반응하지 않도록 한 다.

유리기 형성에는 iron이나 copper같은 금속성이온의 농도도 중요하다. 금속성이온은 전술한 바와 같이 Harber-Weiss반응에 참여하여 $\mathrm{O}_{2}^{-} \cdot$ 과 $\mathrm{H}_{2} \mathrm{O}_{2}$ 로부터 $\mathrm{OH}^{-}$을 생성하기 때문이다. 그 외에도 지질의 과산화를 촉진시켜 cytotoxic aldehyde를 만들며 catecholamines과 thiols을 호소의 도움없이 산화시켜 $\mathrm{O}_{2}^{-} \cdot$ 과 $\mathrm{H}_{2} \mathrm{O}_{2}$ 를 만들고 이들로부터 다시 $\mathrm{OH}$ - 형성을 가능케한다'>
Table 2. Role of Metal lons in Converting Less Reactive Species to More Reactive Species

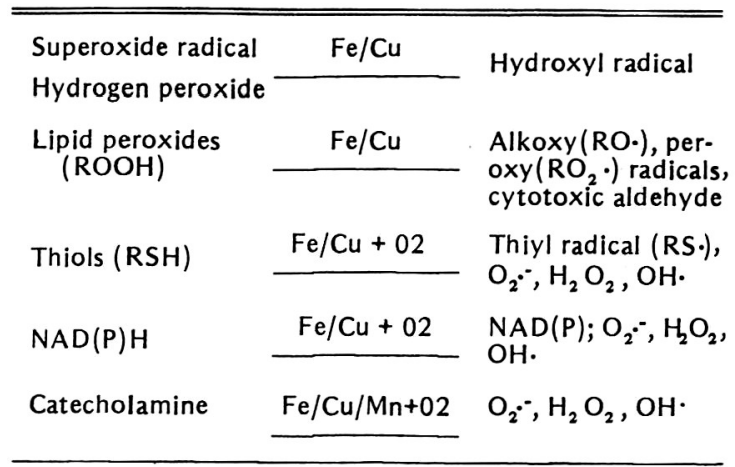

(Table 2). 따라서 다른 유리기에 비해 $\mathrm{OH}$ - 의 강한 반응성을 고려할 때 plasma내의 유리금속성이온(free metalic ion)을 차단시켜 $\mathrm{OH} \cdot$ 이 생길수 있는 반응을 억제시키는 것도 중요할 것이다 ${ }^{17}$.

금속성이온이 관여하는 반응은 세포외 부위가 특히 중 요한데 그 이유는 Haber-Weiss반응을 일으키기 위한 기질, 즉 $\mathrm{O}_{2}^{-} \cdot$ 이나 $\mathrm{H}_{2} \mathrm{O}_{2}$ 가 식세포로 부터 세포외부위 에 많이 분비되고 또 이 부위는 세포내에 비해 상대적으 로 antioxidant효소계가 덜 발달되어 있기 때문이다.

실제 이와같은 금속성 이온이 유리기형성에 참여할 수 없도록 plasma내에는 많은 당단백들이 유리 금속성이 온을 차단하고 있다.

Plasma내에서 free iron은 ferric iron형태로서, transferrin이나 lactoferrin같은 당단백에 결합하는데 이때 iron은 결합부위의 특이성때문에 Haber-Weiss반 응에 참여하지 못한다. 그런데 건강한 개체에서는 당단 백과의 결합이 $30 \%$ 미만정도만 이루어져 있어, oxidant 에 의한 공격시 금속이온이 당단백과 결합할 수 있어 방 어기전으로서 중요한 역할을 하고 있다. 특히 lactoferrin 은 iron과 친화성이 강하며 활성화된 식세포나 허혈성 조직주변의 낮은 $\mathrm{pH}$ 에서는 더욱 친화성이 증가된다고 한다.

Celluloplasmin도 이와같은 당단백의 일종으로 celluloplasmin feroxidase에 의해 $\mathrm{Fe}^{2+}$ 를 $\mathrm{Fe}^{3+}$ 로 변화시 킨후 transferrin과 결합하게 하며 그 자신도 copper와 결합한다.

세포내에서는 iron이 대부분 ferritin에 결합되어 있거 나 "transient iron pool" (유기산, 막의 지질성분 또는 
phosphate esters에 결합되어 있는 iron) 내에 있으므 로 유리기 생성에 관여할 수 없다. 그러나 만일 세포손 상에 의해 세포가 파괴되면 이들 iron이 세포밖으로 나 오는데, ferritin iron은 ascorbic acid와 반응하거나 organic radicals, 식세포로 부터 나온 $\mathrm{O}_{2}^{-} \cdot$ 과 반응하 여 쉽게 유리iron이 되어 지질과산화나 $\mathrm{OH}$ - 생성에 관 여하게 된다 ${ }^{18}$.

\section{2. 생성되는 유리기의 제거}

유리기가 반응성이 적은 물질로 되거나 제거되기 위해 서는 SOD같은 metalloenzymes이나 수용성, 지용성물 질 또는 albumin같은 고분자량물질등의 작용에 의해 가 능하다.

$$
\mathrm{O}_{2}^{-} \cdot+\mathrm{O}_{2}^{-} \cdot+2 \mathrm{H}^{+} \rightarrow \mathrm{H}_{2} \mathrm{O}_{2}+\mathrm{O}_{2}
$$

$\mathrm{SOD}$ 는 위의 반응에서 촉매작용을 하는데 ${ }^{19)}$ 자발적으 로 일어날때보다 무려 $10^{4}$ 정도나 빠른 속도로 dismutation 된다. 포유류세포의 cytosol이나 간혹 핵 에서 볼수 있는 $\mathrm{SOD}$ 는 copper $\left(\mathrm{Cu}^{2+}\right)$ 와 $\mathrm{Zinc}\left(\mathrm{Zn}^{2+}\right)$ 가 결합되어 있는 cuprozinc-SOD (CuZn-SOD)이며 이때 $\mathrm{Cu}$ 가 촉매작용을 하고 $\mathrm{Zn}$ 는 효소 단백구조의 유지에 기 여한다. 촉매작용에서 $\mathrm{Cu}^{2+}$ 는 $\mathrm{Cu}^{1+}$ 로 환원되었다가 다 시 재산화 된다이.

$$
\begin{aligned}
& \mathrm{Cu}^{2+}-\mathrm{SOD}+\mathrm{O}_{2}^{-} \cdot \rightarrow \mathrm{Cu}^{1+}-\mathrm{SOD}+\mathrm{O}_{2} \\
& \mathrm{Cu}^{1+}-\mathrm{SOD}+\mathrm{O}_{2}^{-} \rightarrow \mathrm{Cu}^{2+}-\mathrm{SOD}+\mathrm{H}_{2} \mathrm{O}_{2}+ \\
& 2 \mathrm{H}^{+}
\end{aligned}
$$

이 효소는 간이나 뇌, 고환세포에 많으며 폐세포에는 적은 것으로 알려져 있다.

유핵세포는 mitochondria내에 manganese를 함유하 고 있는 $\mathrm{SOD}$ 를 갖고 있는데, 마찬가지로 $\mathrm{Mn}-\mathrm{SOD}$ 도 활성부위의 $\mathrm{Mn}^{3+}$ 가 $\mathrm{O}_{2}{ }^{-}$- 과 반응할때 환원과 산화반응 을 번갈아 하면서 $\mathrm{O}_{2}^{-} \cdot$ 을 dismutation시킨다.

그외에 세포외부위에는 copper를 함유하는 $\mathrm{Cu}-\mathrm{SOD}$ 가 있으나 폐전체 SOD의 $5 \%$ 미만이며 주로 plasma에 위치하고 있다.

Catalase는 SOD와 더불어 가장 중요한 antioxidant 효소중의 하나로 아래와 같은 반응을 촉매한다.

$$
\mathrm{H}_{2} \mathrm{O}_{2}+\mathrm{H}_{2} \mathrm{O}_{2} \rightarrow 2 \mathrm{H}_{2} \mathrm{O}+\mathrm{O}_{2}
$$

이 효소는 세포의 peroxisome에 많으며 사람에서는 간세포나 적혈구에 많고 뇌, 췌장, 폐세포에는 비교적 적다고 한다 ${ }^{18)}$.

주로 $\mathrm{O}_{2}{ }^{-} \cdot$ 의 dismutation이나 환원형 flavo-효소의

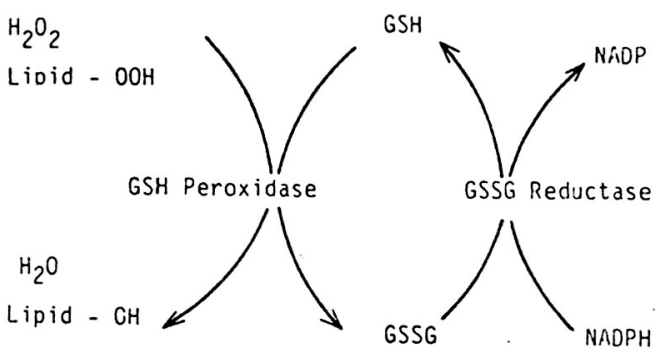

Fig. 4. Glutathione redox cycle. GSH: reduced glutathione, GSSG: oxidized glutathione.

재산화시 생성되는 $\mathrm{H}_{2} \mathrm{O}_{2}$ 를 제거한다 ${ }^{19)}$.

$\mathrm{H}_{2} \mathrm{O}_{2}$ 는 peroxidase에 의해서도 제거될 수 있는데 포 유류 조직에서 가장 중요한 것은 glutathione peroxidase (GSH-PX)이다.

GSH-PX는 glutathione thiol (GSH)을 glutathione disulfide (GSSG)로 산화시키면서 동시에 $\mathrm{H}_{2} \mathrm{O}_{2}$ 를 두분 자의 $\mathrm{H}_{2} \mathrm{O}$ 로 환원시킨다. 이때 산화형의 $\mathrm{GSSG}$ 는 다시 $\mathrm{NADPH}$ 와 $\mathrm{GSH}$ reductase에 의해 $\mathrm{GSH}$ 로 재환원되 어 반복해서 glutathione redox cycle을 이루면서 $\mathrm{H}_{2}$ $\mathrm{O}_{2}$ 나 다불포화지방산 (polyunsaturated fatty acid)의 peroxidation시 생기는 지방산 hydroperoxide (lipid$\mathrm{OOH}, \mathrm{ROOH}$ )를 제거시킨다(Fig. 4).

이 효소는 대부분이 cytosol에 있으며, 평상시는 catalase보다 $\mathrm{H}_{2} \mathrm{O}_{2}$ 제거능력이 더 크나 $\mathrm{H}_{2} \mathrm{O}_{2}$ 생성이 증 가되면 catalase가 더 중요한 효소로 작용한다.

폐포내에서는 상피세포를 덮고 있는 액체에도 plasma보다 100 배 정도나 더 많은 $\mathrm{GSH}$ 가 있고 catalase도 많으며 $\mathrm{GSH}$ 의 대부분이 환원형으로, alveolar macrophage로부터의 $\mathrm{H}_{2} \mathrm{O}_{2}$ 에 대해 방어하기 에 충분하다. GSH는 확실치는 않으나 아마도 상피세포 에서 분비되는 것으로 보인다.

지용성물질로서 vitamin-E ( $\alpha$-tocopherol)는 지방산 radical $\left(\mathrm{RO}_{2} \cdot\right)$ 을 반응성이 제한되어 있는 $\alpha$ tocopherol radical $(\alpha-\mathrm{T} \cdot)$ 로 만들며 $\alpha$ - $\mathrm{T}$-은 ascorbic acid에 의해 다시 환원형으로 되돌아 온다. 이러한 반응 에 의해 지질로 되어있는 세포막의 손상을 줄일 수 있 다.

그 밖에 $\beta$-carotene은 $\mathrm{O}_{2}^{-} \cdot$ 을 직접 제거하거나 peroxyl radical과 반응하여 지용성-antioxidant역할을 한 다. 
수용성 antioxidant로는 vitamin-C, 뇨산, taurine등 이 있다.

Vitamin-C는 세포내외에 광범위하게 용해될 수 있어 이론적으로는 이상적인 antioxidant라 할수 있다. Vitamin-C는 직접 $\mathrm{O}_{2}^{-}$- 이나 $\mathrm{OH}^{-}$과 반응하여 semidehydroascorbate유리기를 형성한 후 GSH에 의 해 환원되면서 dehydroascorbate와 GS - 를 형성한다. dehydroascorbate는 다시 GSH-의존성 dehydroascorbate reductase에 의해 ascorbate와 GSSG를 생성 시킨달. 그러나 vitamin-C는 prooxidant성질때문에 중요한 antioxidant로 인정받지 못하고 있다. 즉 vitamin $-\mathrm{C}$ 는 $\mathrm{Fe}^{3+}$ 를 $\mathrm{Fe}^{2+}$ 로 환원시켜 $\mathrm{Fe}^{2+}$ 가 $\mathrm{H}_{2} \mathrm{O}_{2}$ 와 반응하여 $\mathrm{OH}^{-}$을 생성할 수 있기 때문이다.

따라서 vitamin-c는 iron농도에 따라 유리기에 대해 생체에 이롭게 작용할 수도 있고 그렇지 못할때도 있는 것이다 ${ }^{18)}$.

Uric acid (노산)은 강력한 antioxidant로서22) 직접 $\mathrm{OH} \cdot$ 이나 ${ }^{1} \mathrm{O}_{2}$, oxoheme oxidants 및 지질과산화에 의 해 생성된 peroxyl radical을 제거한다.

Taurine은 $\beta$-아미노산으로 대부분의 장기세포내외 에 있으며 ${ }^{23)} \mathrm{HOCl}$ (hypochlorous acid) 와 반응하여 반응성이 약한 물질로 만든다.

고분자량물질의 antioxidants로는 기관지 점액이나 albumin을 들 수 있다. 기관지 점액은 상피세포에서 합 성된 고분자량의 mucopolypeptide당단백이 있어 담배 연기속의 반응성 oxidants를 제거하여 상피세포를 보호 한다. Albumin 은 iron이나 copper 와 결 합하여 Haber-Weiss반응에 이용되지 못하도록 한다.

이와같이 다양한 antioxidant system 외에도, 과량 의 유리기가 폐세포를 공격할 때는 혈액내에 있는 적혈 구나 혈소판도 방어인자 역할을 한다.

적혈구는 SOD, catalase, GSH redox cycle등의 풍 부한 antioxidant system을 갖고 있어 적혈구막을 통해 들어온 $\mathrm{O}_{2}^{-}$- 을 dismutation시키고 아울러 중성구에서 나온 $\mathrm{H}_{2} \mathrm{O}_{2}$ 를 대사할 수 있다. 뿐만아니라 oxidants에 노출되었을때 적혈구는 혈관내피세포에 가깝게 달라붙 어 $\mathrm{O}_{2}{ }^{-}$- 이나 $\mathrm{H}_{2} \mathrm{O}_{2}$ 를 한곳으로 모으고 $\mathrm{OH}$ - 같은 반응 성이 더 강한 유리기의 형성을 막아준다 ${ }^{28)}$.

혈소판도 catalase와 GSH redox cycle기능을 많이 갖고있다. 혈소판은 $\mathrm{H}_{2} \mathrm{O}_{2}$ 에 의해 서로 응집되는데 이때 활성화된 중성구로부터의 oxidants를 감소시킬 수 있
다.

Alveolar macrophage나 단핵구, 중성구같은 식세포 들도 일차적으로는 유해물질이나 세균에 대해 살균작용 을 하기위해 $\mathrm{H}_{2} \mathrm{O}_{2}$ 를 만들어 내지만 상당량의 antioxidants를 갖고 있어 유리기에 대해 방어작용을 한 다.

\section{Oxidants에 의한 세포손상의 회복}

손상받은 세포부위의 복구기전에 대해서는 아직까지 확실히 밝혀져 있지 않다.

그러나 지금까지 알려진 바에 의하면, 손상받은 세포 부위가 repair효소에 의해 수선되거나 제거되고, 손상 부위 조직을 대신할 수 있도록 세포의 증식이 있는 것으 로 보인다 ${ }^{18)}$.

분자구조의 복구는 주로 핵산에 대한 방사선조사나 암 유발과정에 의해 연구되고 있다.

유리기가 pyrimidine의 deoxyribose sugar와 phosphate결합을 공격하면 nucleotide로부터 손상받은 염기 가 떨어져 나간다.

유리기에 의한 내피세포손상을 실험한 결과 $\mathrm{H}_{2} \mathrm{O}_{2}$ 가 세포내의 $\mathrm{Fe}^{2+}$ 와 결합하여 $\mathrm{DNA}$ strand를 갈라놓기도 한다 ${ }^{24)}$. 이때 손상의 정도가 심하지 않을때는 protein-ADP ribosyl transferase가 활성화되어 손상부위 를 절단하여 복구한다. 세포막에서는 phospholipase $\mathrm{A}_{2}$ 와 phospholipid hydroperoxide GSH-PX 가 주로 과산화한 세포막 인지질을 제거시키는데 ${ }^{25)}$ 이들 효소의 주된 역할은 지질의 과산화가 일어나기 전에 세포막의 손상부위를 제거시키는 것이다.

손상받은 조직을 대치하기 위한 세포의 증식도 중요한 복구기전의 하나이다. Rat를 hyperoxia에 노출시킬때 초기에는 세포의 복제가 억제되나 60시간이후부터는 $\mathrm{DNA}$ 합성이 증가되고 type II 상피세포의 증식과 type I 세포의 비후를 볼 수 있다 ${ }^{26,27)}$. 뿐만아니라 모세혈관 내피세포의 수적인 증가와 비후현상을 볼 수 있다.

이와같이 세포증식을 자극하는 물질이 무엇인가는 아 직 확실치 않으나 polyamines일 것으로 추측하고 있다.

\section{산소 유리기와 관련된 호흡기 질환}

\section{Hyperoxia에 의한 폐손상}

Hyperoxia상태에 장시간 노출되면 세포나 조직손상 
에 따른 여러가지 독성반응이 나타나는데, 이와같은 폐 손상은 생성되는 산소유리기가 폐의 antioxidant능력을 초과하기 때문이라고 여겨진다. Hyperoxia에 의해 세 포나 여러부위에서 생성된 유리기는 일차적으로 세포막 을 공격하며 lipid peroxidation에 의해 막이 손상을 입 게되면 막투과성이 증가된다. 아울러 이차적으로는 sulfhydryl group을 갖는 세포내 효소나 내피세포의 구 조물들을 공격하여 세포의 기능과 구조를 무너뜨리게 된 다.

전자현미경으로 관찰한 rat실험에서 가장 먼저 나타 나는 변화는 폐부종때문에 간질간격이 두배정도 넓어지 는 것이며 이어서 간질세포와 간질 matrix 가 증가한다. 모세혈관의 내막세포도 비교적 초기에 손상을 받는데 cytoplasm의 변화에 이어 세포가 세분되어 파괴된 다 ${ }^{34,35)}$.

그러나 치사량이하의 hyperoxia상태에서는, 세포침 윤과 함께 염증반응기를 거쳐 혈관내피세포가 일부 파괴 되지만, 결국 세포소기관들의 증식과 함께 상피세포, 간 질세포, alveola septum의 내피세포가 증식되어 산소 에 내성을 획득한다고 한다.

\section{2. 성인성호흡장애 증후군}

성인성호홉장애 증후군(ARDS)은 여러가지 원인에 의해, 폐에 미만성 손상이나 폐외손상을 받은 후, 임상 적으로 급격하게 호흡곤란과 함께 폐침윤을 보이는 일련 의 증후를 말하는데, 이의 병태생리에도 반응성 산소대 사물이 관여하고 있다. 특히 폐혈관 내막세포와 중성구 의 관계가 중요한데, 중성구를 비롯한 식세포들이 활성 화되면 반응성 산소대사물이 많이 배출되고 따라서 혈관 투과성이 증가된다 ${ }^{29,30)}$. 증가된 혈관의 투과성 결과 폐 포나 간질의 수종이 초래되는 것이다. 혈관 내막세포에 손상을 가장 많이 주는 것은 $\mathrm{H}_{2} \mathrm{O}_{2}$ 로서 이 유리기로부터 가장 반응성이 강한 $\mathrm{OH}$ - 이 생성될 수 있기 때문이다.

산소 대사물은 또, 간접적으로 antiprotease를 불활 성화시켜 미세혈관이 중성구의 elastase에 쉽게 손상을 받게 한다 ${ }^{31}$.

산소 대사물이 직접 사람의 $\mathrm{ARDS}$ 에서 어떤 역할을 하는지는 분명하지 않으나 ARDS 환자의 호기내에 $\mathrm{H}_{2}$ $\mathrm{O}_{2}$ 농도가 증가되거나 ${ }^{32)}$, 혈중의 lipid peroxide농도가 증가되머 기관지폐포세척액에서는 산화된 antiprotease 농도가 증가되었다는 보고도 있다 ${ }^{33)}$.

\section{Xenobiotics에 의한 손상}

Bleomycin을 비롯한 xenobiotics는 세포내의 환원효 소에 의해 활성화되고 다시 산화되는 redox cycling을 반복하는데 이때 세포내에서 생성되는 유리기에 의해 세 포손상이 일어난다.

Bleomycin은 항암제로 사용되는 당단백의 혼합물로 서, 중요한 부작용은 폐 석유화중이다. 실험적으로는 직 접 기관지투여시 쉽게 폐손상을 일으켜 급성폐손상의 표 본으로 자주 이용된다. 병리학적으로는 폐실질의 많은 세포들이 alveolitis형태로 손상을 받고 결국 섬유화된 다.

Bleomycin은 특히 DNA와 친화성이 강해 iron이 있 을때 DNA-bleomycin- $\mathrm{Fe}^{2+}$ 복합체를 형성한다. 이 복 합체는 redox cycling에 의해 핵내에서 반응하여 $\mathrm{O}_{2}{ }^{-}$을 형성하고 $\mathrm{O}_{2}{ }^{-}$- 은 다시 $\mathrm{H}_{2} \mathrm{O}_{2}$ 와 반응하여 $\mathrm{OH} \cdot$ 을 만드는데 ${ }^{36)}$, 이때 bleomycin이 DNA의 double strand 나 single strand와 결합해 있으므로 이들 유리기에 의 해 DNA가 쉽게 손상을 받게된다.

Paraquat는 bipyridylium계의 제초제로서 지난 수십 년간 수많은 사람들이 이 제재에 의한 중독으로 희 생되 었다. Paraquat는 체내의 여러장기에 독성을 나타내지 만, 폐에서는 에너지의존성과정에 의해 농도경사를 거 슬러 흡수되므로 특히 심한 손상을 받는다. Paraquat는 bipyridylium $\left(\mathrm{BP}^{2+}\right)$ 상태로 세포막을 통과한 후 mitochondria의 electron transport chain으로부터 전 자를 받아 bipyridyl radical (BP. $\left.{ }^{+}\right)$을 형성한다 ${ }^{10)}$. 이 유리기가 산소분자와 반응할때 산소분자를 환원시키면 서 $\mathrm{BP} \cdot{ }^{+}$은 $\mathrm{BP}^{2+}$ 으로 되돌아가고 이때 $\mathrm{O}_{2}^{-} \cdot$ 이 생기 게 된다(Fig. 5).

이러한 반응은 산소와 전자를 제공하는 $\mathrm{NADPH}$ 가 남아있을때까지 진행되는데 이때 생성되는 유리기에 의 해 세포막의 lipid peroxidation이 일어나고 세포파괴가 진행된다.

Nitrofurantoin은 급·만성요로계 감염에 많이 사용

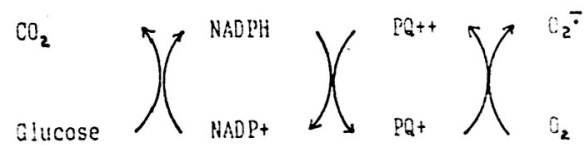

Fig. 5. Activation of paraquat. Superoxide anion is formed during this redox cycling. 
되는 항생제로서, paraquat와 유사한 기전에 의해 유리 기를 생성한다. Nitrofurantoin은 폐 microsomes에서 $\mathrm{NADPH}$ 로부터 전자하나를 받아 nitroanion유리기로 대사된 후 이 유리기가 산소분자와 다시 반응하여 $\mathrm{O}_{2}{ }^{-}$. 을 형성하고 원래의 nitrofurantoin으로 되돌아 간다 (Fig. 6).

\section{4. 흡연과 폐기종}

흡연시 한번 들이마시는 흡기속에는 peroxides, aldehydes, epoxides를 포함한 $10^{16}$ 개의 oxidants가 들어있 어 하부기도세포에 손상을 주기에 충분하다고 한다 ${ }^{19)}$. 더우기 흡연시에는 하부기도에 중성구의 수가 증가되 어 ${ }^{37)}$ oxidants 생성이 더욱 많아지고 ${ }^{38)}$, 따라서 antioxidant의 고갈을 초래할 수 있다고 한다 ${ }^{39)}$.

이와같은 직접적인 작용이외에 oxidants는 alpha-1antiprotease의 methionine을 methionine sulfoxide로 산화시켜 불활성화 시킨다. 따라서 중성구 elastase에
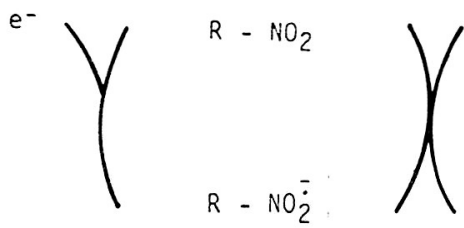

$0 ;$

Fig. 6. Reduction of nitrofurantoin $\left(\mathrm{R} \cdot \mathrm{NO}_{2}\right)$ to a free radical metabolite.
의한 폐조직파괴에 방어를 할 수 없게되며, 이와같은 현 상이 폐기종의 병태생리에 중요한 역할을 하리라고 본 다 ${ }^{40)}$ (Fig. 7).

\section{5. 허혈상태후 재관류에 의한 폐손상}

허혈상태후 재관류시의 폐손상은 혈류재개와 더불어 이루어지는 산소재공급과 관련이 있으며, 특히 반응성 산소 대사물인 산소유리기가 세포손상을 야기하는 직접 적인 인자가 될 것으로 보고되어, 최근 많은 관심을 끌 고 있다.

허혈상태에서는 세포의 저장에너지가 고갈되고 따라 서 adenosine triphosphate (ATP)가 여러단계를 거쳐 hypoxanthine으로 된다(Fig. 8).

에너지가 낮아지면서 세포내외의 양이온경사는 작아 지고 cytosol의 칼슘이온농도가 증가하게 된다. 증가된 칼슙은 proteinase를 활성화시켜 xanthine dehydrogenase $(\mathrm{XD})$ 를 xanthine oxidase $(\mathrm{XO})$ 로 전 환시 키는데, $\mathrm{XD}$ 는 건강한 조직에서는 $\mathrm{XO}$ 활성도의 $90 \%$ 을 담당하며, 이 효소는 전자수용체로 산소분자대신 isocitrate dehydrogenase를 이용하므로 반응결과 산소유 리기가 생기지 않는다. 그러나 허혈상태에서 $\mathrm{XD}$ 가 $\mathrm{XO}$ 로 전환되면 이 효소는 hypoxanthine을 xanthine으로 반응시키고 이어서 $\mathrm{O}_{2}$ 의 존재하에 노산과 산소유리기를 생성하게 된다 ${ }^{41)}$. 즉 허혈상태는 세포내의 hypoxanthine농도와 XO활성도를 증가시키고 재관류가 될

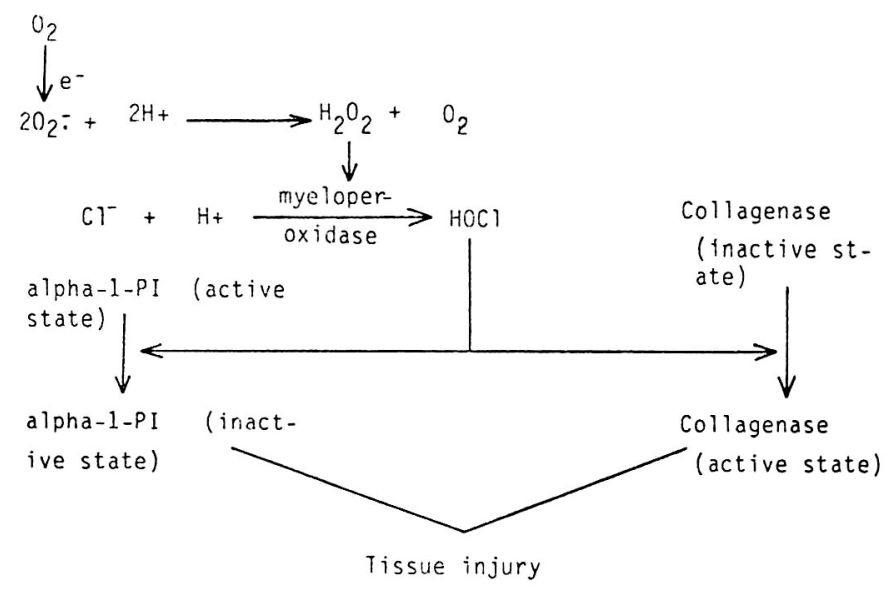

Fig. 7. Proposed relationships among neutrophil derived HOCL, alpha-1-protease inhibitor, collagenase, and tissue injury. 


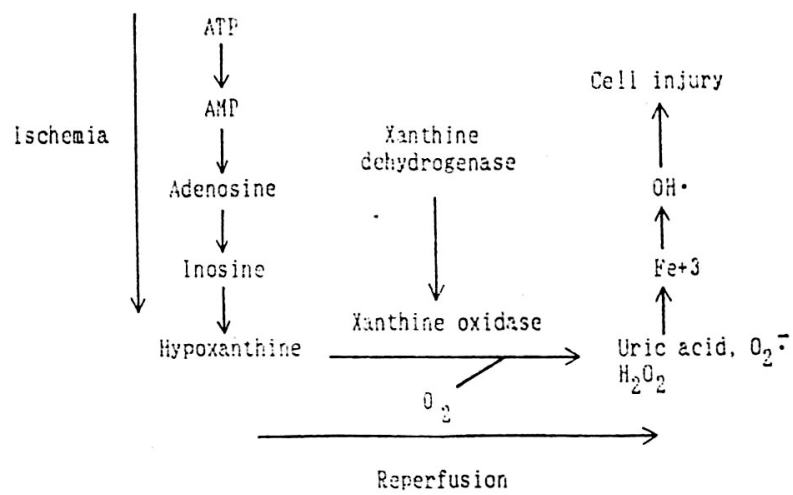

Fig. 8. Proposed mechanism of reperfusion lung injury.

때 공급되는 산소에 의해 반응성 산소대사물이 생겨 조 직손상을 가중시키는 것이다. 그러나 사람의 폐조직에 는 세포내의 XO활성도가 낮기때문에 허혈성 폐손상시 산소대사물의 생성부위가 다른곳일 가능성을 배제할 수 가 없다고 한다 ${ }^{18}$.

\section{Inorganic Dust의 흡입}

장기간 asbestos, 특히 crocidolite에 노출될 때 oxidants에 의한 폐손상을 볼 수 있으며, 산소유리기에 대한 방어기전도 증가된다고 한다. 이러한 반응은 확실 치는 않으나 alveolar macrophage 표면의 당단백에 asbestos 입자가 결합하여 반응성 산소유리기를 방출한 다고 한다.

Crystalline silica는 $\mathrm{Si}-\mathrm{O}_{2} \cdot$ 유리기를 만들며 또한 alveolar macrophage에 노출되면 $\mathrm{O}_{2}^{-} \cdot$ 과 $\mathrm{H}_{2} \mathrm{O}_{2}$ 의 유 리를 촉진시킨다.

\section{Antioxidant System의 증진을 위한 약리학적 방법}

산소유리기에 대한 방어기전을 증가시킬 수 있는 약리 학적 방법은 크게 두가지로 요약할 수 있다.

하나는 개체내의 antioxidant system을 증가시키는 것이고 다른 하나는 이미 생성된 반응성 물질들을 제거 시키는 것이다.

세포의 antioxidant system을 증진시키는 방법은 다 양하게 연구되어지고 있다. 가장 간단한 방법은 세포의 antioxidant효소를 증가시키는 것인데, 실제로 $\mathrm{SOD}$ 나 catalase를 외부에서 투여했을때 이의 효과에 대해서는
아직 이론이 많다. 그 이유는 효소들의 분자량이 커서 세포내로의 이동이 어렵기 때문이다. 특히 catalase는 정상세포막을 통과할 수 없으며 SOD도 거의 통과하지 못한다. 그러나 oxidants에 의해 막이 손상되어 투과장 벽이 깨지면 어느정도는 세포내로 유입될 수 있다. 따라 서 외부에서 투여한 효소는 주로 세포외부위의 oxidants를 제거하는 효과를 갖을 뿐이다.

이러한 문제를 해결하기 위해 liposome으로 효소를 캡슐화시켜 세포로 하여금 endocytosis하게 한 결과 $\mathrm{SOD}$ 의 경우는 세포내 농도가 6 12배, catalase는 6배 정도 증가될 수 있었고 효소의 반감기도 증가되었다고 한다 ${ }^{42,43}$. 그러나 liposome이 모든 동물에서 똑같이 대 식작용에 의해 세포내로 받아들여지지 않는 것이 문제이 다.

Corticosteroids는 세포로부터 antioxidant효소의 유 리를 촉진시키는데 SOD의 경우 $72 \%, \mathrm{GSH}-\mathrm{PX}$ 는 $94 \%$ 정도의 효소농도가 상승한다고 한다. 폐세포를 hyperoxia상태에 노출시킨 실험에서도 corticosteroid투여 는 산소독성에 대한 내성발현을 증가시킨다고 한다 ${ }^{18)}$. 그러나 이러한 효소의 유도가 모든 실험동물에서 다 일 어나지는 않는다.

그외에 GSH의 외부적인 투여나 GSH의 세포막 투과 롤 증진시키는 GSH의 methylester, diethylmalate 또 는 $\mathrm{GSH}$ 의 전구물질인 cystein의 외부투여가 연구되고 있다.

한편 oxidants가 생성되는 곳에서 iron을 이용할 수 없도록 chelation시키는 방법도 시도되고 있는데 chelater로는 주로 deferoxamine이 이용된다. 그러나 급성 폐손상시의 효과에 대한 연구에서는 ${ }^{18,44)}$ 이 제재 자체의 
독성문제가 거론되고 있다.

$\alpha$-Tocopherol은 지방산 radical과 반응하여 $\alpha$-tocopherol radical로 되는데 이 유리기는 더 이상 유리기 chain을 이어갈 수 없기 때문에 세포막의 손상을 보호해 줄 수 있다. 그러나 가장 큰 문제점은, 급성 폐 손상시 투여했을 때 너무 서서히 축적되어 조직내 농도가 증가 되기 까지는 일주일 정도나 걸리고 이미 그 사이에 세포 막 손상은 진행되는 것이다. 그러나 liposome으로 캡슐 화 한후 투여했을때는 6 시간내에 세포내 농도가 12 배정 도 증가 한다고 한다 ${ }^{18)}$. $\mathrm{N}$-acetylcysteine은 직접 $\mathrm{H}_{2}$ $\mathrm{O}_{2}, \mathrm{O}_{2}^{-} \cdot, \mathrm{OH}^{-}$을 반응성이 약한 유리기로 전환시키며 cystein으로 deacetylate되어 GSH합성을 증가시켜 준 다.

Dimethylthiourea도 $\mathrm{OH}^{-}, \mathrm{H}_{2} \mathrm{O}_{2}, \mathrm{HOCl}$ 등을 제거 하여 과립구의 chemotactic factor 생성을 억제한다. 세포막을 비교적 잘 통과하나 antioxidant 효소들에 비 해 산소대사물의 제거 능력이 제한되어 있다.

Allopurinol이나 이의 대사물인 oxypurinol은 xanthine oxidase에 의한 조직손상을 보호해 준다. Allopurinol은 이 반응에서 기질로 사용되어 xanthine 이나 hypoxanthine 대신 들어가 노산의 형성을 방해하 기 때문에 산소유리기 생성을 억제시킬 수 있다.

Oxypurinol은 실질적인 xanthine oxidase 억제제로 서 $\mathrm{O}_{2}{ }^{-} \cdot$ 을 생성하지 못하게 한다.

Tungsten도 이와같은 xanthine oxidase 억제제의 하나이다.

이와같이 여러 약제나 화학물질에 의한 antioxidant 효과의 증진외에도 앞으로는 유전자 수준에서 antioxidant 생성을 조절하고 유도시키는 분자생물학적 차원 의 방어기전에 대한 연구가 활발히 진행되리라 본다.

실제로 실험동물을 hyperoxia에 노출시켰을때 $\mathrm{CuZn-SOD-m-RNA}$ 가 양적으로 증가되고, 내독소 투여 시에도 tissue necrosis factor (TNF)나 interleukin-1 같은 cytokines산물에 의해 Mn-SOD-m-RNA가 증가 되면서 antioxidant가 유도된다고 하였다. 아울러 산소 유리기에 저항성이 높거나 antioxidant를 다량 분비할 수 있는 cell clones의 합성도 recombinant gene technology에 의해 가능할 것으로 보인다.

\section{결 론}

호기성 대사를 영위하는 생체세포는 4 개의 전자를 수 용하여 최종적으로는 $\mathrm{H}_{2} \mathrm{O}$ 로 환원되지만 그 중간과정에 서 부분적으로 환원된 산소유리기를 생성하게 된다. 일 반적으로 유리기는 전자쌍을 이루지 못한 불안정한 분자 로써, 또다른 전자를 수용하거나 공여하여 전자쌍을 이 룬 보다 안정된 상태로 돌아가려 한다.

따라서 생체내에서는 유리기의 이러한 특성때문에 각 종 단백이나 불포화지방이 산화되고 핵산이 손상을 받으 며 세포가 파괴된다.

폐는 특히 유리기 생성과 관련이 있는 많은 대기중의 물질들과 접하고 있고, 또 이들에 대해 아주 예민하게 반응한다. 즉 정상세포에는 antioxidant효소계와 수용 성, 지용성 antioxidants, 단백질 같은 고분자량의 antioxidant가 있어 이들이 직접 또는 상호작용하여 세 포로부터 유리되는 반응성 산소대사물을 제거시키기 때 문에 독작용을 나타내지 못한다. 그러나 이들 방어기전 이 저하 되거나 또는 산소유리기의 생성이 방어기전을 능가할 정도로 과다한 경우는 세포손상이 일어날 수 있 을 것이다. Hyperoxia에 의한 폐손상, xenobiotics, inorganic dust, smoke에 의한 폐손상이나 ARDS, 허 혈상태후 재관류손상등 많은 폐질환에서 산소유리기가 관련있는 것으로 알려져 있다. 이와같은 유리기에 의한 폐손상을 막기 위해 antioxidant system을 증진시키기 위한 많은 연구가 진행중이며, 점차 유리기와 관련된 폐 질환도·정복되리라 믿는 바이다.

\section{REFERENCES}

1) Halliwell B: A radical approach to human disease. Upjohn Symposium/Oxygen Radicals, 139-143, 1987

2) McCord JM, Fridovich I: Superoxide dismutase. An enzymic function for erythrocuprein (hemocuprein). J Biol Chem 224:6049-6055, 1969

3) Jenkinson SG: Pulmonary oxygen toxicity. Clin Chest Med 3:109, 1982

4) 정명희 : 식세포의 산소의존성 살균작용. 대한화학요 법학회지 2:529-543, 1984

5) Jenkinson SG: Free radical effects on lung metabolism. Clin Chest Med 10:37-47, 1989 
6) Winston GW, Cederbaum AI: NADPH dependant production of oxy-radicals by purified components of the rat liver mixed function oxidase system. J Biol Chem 258:1508-1513, 1983

7) Pryor WA: Oxy-radicals and related species: Their formation, lifetimes, and reactions. Ann Rev Physiol 48:657-667, 1986

8) Bielski BHJ, Arudi RL, Sutherland MW: A study of the reactivity of $\mathrm{HO}_{2} / \mathrm{O}_{2}{ }^{-}$with unsaturated fatty acids. J Biol Chem 258:4759-4761, 1983

9) Deneke SM, Fanburg BL: Normobaric oxygen toxicity of the lung. $N$ Engl J Med 303:76, 1980

10) Smith LL: The response of the lung to foreign compounds that produce free radicals. Ann Rev Physiol 48:681-692, 1986

11) McCord JM: Oxygen-derived free radicals in postischemic tissue injury. N Engl J Med 312:159-163, 1985

12) Turrens JF, Boveris A: Generation of superoxide anion by NADH dehydrogenase of bovine heart mitochondria. Biochem J 191:421-427, 1980

13) Lawrence RA, Burk RF: Glutathione peroxidase activity in selenium deficient rat liver. Biochem Biophys Res Commun 71:952, 1976

14) Tate RM, Repine JE: Neutrophils and adult respiratory distress syndrome. Am Rev Respir Dis 28:552, 1983

15) Aleman V, Handler P: Dehydroorotate dehydrogenase. J Biol Chem 242:4087-4096, 1967

16) Brunori M, Rotilio G: Biochemistry of oxygen radical species. Methods Enzymol 105:22-35, 1984

17) Halliwell B, Gutteridge JMC: Oxygen free radicals and iron in relation to biology and medicine: some problem and concepts. Arch Biochem Biophys 246: 501-514, 1986

18) Heffner JE, Repine JE: Pulmonary strategies of antioxidant defense. Am Rev Respir Dis 140:531 $-554,1989$

19) Fridovich I, Freeman B: Antioxidant defenses in the lung. Ann Rev Physiol 48:693-702, 1986

20) Blackburn NJ, Hasnain SS, Binstead N, Diakun GP, Garner GD, Knowles PF: An extended x-ray absorption fine structure study of bovine erythrocyte superoxide dismutase in aqueous solution. Direct evidence for three coordinate $\mathrm{Cu}$ (I) in reduced enzyme. Biochem J 219:985-990, 1984

21) Chaudiere J, Tappel AL: Purification and characterization of selenium-glutathione peroxidase from hamster liver. Arch Biochem Biophys 226:448-45i. 1983

22) Ames BN: Dietary carcinogens and anticarcinogens. Science 221:1256-1264. 1983

23) Wright CE. Tallen HH, Lin YY: Taurine: biological update. Ann Rev Biochem 55:427-453, 1986

24) Spragg RG: DNA single strand breaks in bovine endothelial cells results from exposure to extracellular $\mathrm{H}_{2} \mathrm{O}_{2}$ and intracellular products of $\mathrm{H}_{2} \mathrm{O}_{2}$ and iron (abstract). Am Rev Respir Dis 137:84, 1988

25) Ursini F, Maiorino M, Gregolin C: The selenoenzyme phospolipid hydroperoxide glutathione perox idase. Biochem Biophys Acta 839:62-70, 1985

26) Hacker AD, Tierney DF, O'Brien TK, Witschi HP: Hyperoxic lung injury and polyamine biosynthesis: age related differences. Am Rev Respir Dis 132:354 $-357,1985$

27) Thet LA, Parra SC, Shelburne JD: Repair of oxygen induced lung injury in adult rats. The role of ornithine decarboxylase and polyamines. Am Rev Respir Dis 129:174-181, 1984

28) Winterbourn CC, Stern A: Human red cells scavenge extracellular hydrogen peroxide and inhibit formation of hypochlorous acid and hydroxyl radical. J Clin Invest 80:1486-1491, 1987

29) Harlan JM, Killen PD, Harker LA, Striker GE: Neutrophil mediated endothelial injury in vitro. J Clin Invest 68:1393-1403, 1981

30) Shasby DM, Vanventhuysen KM, Tate RM, Shasby SS, Mcmurtry I, Repine JE: Granulocytes mediate acute edematous lung injury in rabbits and in isolated rabbit lungs perfused with phorbol myristate acetate: role of oxygen radicals. Am Rev Respir Dis 125:443-447, 1982

31) Baird BR, Cheronis JC, Sandhaus RA, Berger EM, White CW, Repine JE: Oxygen metabolites and neutrophil elastase synergistically cause edematous injury in isolated rat lungs. J Appl Physiol 61:2224 $-2229,1986$

32) Baldwin SR, Grum CM, Boxer LA, Simon RH. Ketai LH, Devall LJ: Oxidant activity in expired breath of patients with adult respiratory distress syndrome. Lancet 1:11-13, 1986

33) Cochrance CG, Spragg R, Revak SD: Pathogenesis of the adult respiratory distress syndrome: evidence of oxidant activity in bronchoalveolar lavage fluid. $\mathrm{J}$ Clin Invest 71:754-758, 1983

34) Crapo JD: Morphologic changes in pulmonary oxy- 
gen toxicity. Ann Rev Physiol 48:721-731, 1986

35) Jamieson $D$ : The relation of free radical production to hyperoxia. Ann Rev Physiol 48:703-719, 1986

36) Duncan CA: Lung metabolism of xenobiotic compounds. Clinics in Chest Medicine 10:49-58, 1989

37) Hunninghake GW, Gadek JE, Kawanami O, Ferrans VJ, Crystal RG: Inflammatory and immune processes in the human lung in health and disease: evaluation by bronchoalveolar lavage. Am J Pathol 97:149 $-206,1979$

38) Hoidal JR, Fox RB, Le Marbe PH, Perri R, Repine $\mathrm{JE}$ : Altered oxidative metabolic responses in vitro of alveolar macrophages from asymptomatic cigarette smokers. Am Rev Respir Dis 123:85-89, 1981

39) Molde'us P, Cotgreave IA, Berggren M: Lung protection by a thiol containing antioxidant: Nacetylcysteine. Respiration 50:31-43, 1986

40) Weiss SJ, Peppin G, Ortiz X, Ragsdale C, Test ST:
Oxidative autoactivation of latent collagenase by human neutrophils. Science 227:747-749, 1985

41) Grisham MB, Granger DN: Metabolic sources of reactive oxygen metabolites during oxidant stress and ischemia with reperfusion. Clinics in Chest Medicine 10:71-81, 1989

42) Turrens JF, Crapo JD, Freeman BA: Protection against oxygen toxicity by intravenous injection of liposome entrapped catalase and superoxide dismutase. J Clin Invest 73:87-95, 1984

43) Freeman Ba, Young SL, Crapo JD: Liposome mediated augmentation of superoxide dismutase in endothelial cells prevents oxygen injury. J Biol Chem 258:12534-12542, 1983

44) Halliwell B, Gutteridge JMC: Oxygen free radicals and iron in relation to biology and medicine: some problems and concepts. Arch Biochem Biophys 246: 501-514, 1986 